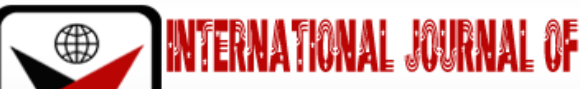

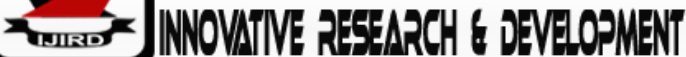

ISSN 2278-0211 (Online)

\section{Leadership Styles, Financial Competency and Survival of Micro, Small and Medium Scale Enterprises in Lagos State, Nigeria}

\author{
Oyewole, AdegboyegaSule \\ Lecturer, Department of Business Education, \\ Michael Otedola College of Primary Education, \\ Noforija-Epe, Lagos State, Nigeria
}

\begin{abstract}
:
Micro Small and Medium Scale Enterprises generally play vital roles in economic growth and development nationwide. In Nigeria, it has not been contributing as expected to Nigerian Gross Domestic Products, despite it has absorbed the largest labour force. This study investigates the influence of leadership styles and financial competency on the survival of Micro Small and Medium Scale Enterprises. The design of the study was descriptive survey research. Eight hundred and thirteen MSMEs staff were randomly sampled from two hundred and seventy-one MSMEs in the three Local Government Area in Lagos State. The results show that transformational and charismatic leadership styles excerpt positive influence while financial knowledge exerts significant negative influence on the survival of Micro Small and Medium Scale Enterprises in Lagos State. It was recommended that Training and retraining is also required in the area of financial literacy for manager/owner to be financially competent.
\end{abstract}

Keywords: Leadership, leadership styles, financial competency, survival, micro small and medium scale enterprises

\section{Introduction}

The concept of Micro Small and Medium Scale Enterprises across different countries and institutional context is plague with controversy (Akabueze, 2002; SMEIS, 2002; Sanusi, 2003; Udechukwu, 2003; Sanusi, 2004 \& National Policy on Education, 2007), although it is generally believed that MSMEs play vital roles in economic growth and development of nationwide. In Nigeria, MSMEs provide employment, reduce poverty and contribute significantly to national income and income per capita. For instance, the sector in Nigeria absorbs 85\%, 84.02\% and 76.5\% of labour force with 46.54\%, $48.47 \%$ and $49.78 \%$ contribution to the GDP in 2010, 2013 and 2016 respectively (NBS \& SMEDAN, 2013; Yemi, 2015; \& NBS \& SMEDAN 2016). These enterprises are set-up not only for profit making but also for growth and survival (Saasongu, 2015). Survival means the business continues to operate as a self-sustaining activity, is effectual in achieving profitability, effective in attracting resources, and is tailored properly to the environment (Neneh, 2011). It is a necessary aspect of performance and an essential condition for sustained business success (Kalleberg and Leicht, 1991). Given the importance of business survival especially in small firms and startup enterprises, the question of why some businesses survives and others do not remain a central focus in entrepreneurship study (Cooper, 1993).

Managers/ owners of MSMEs have to deal with a tough economic challenge in todays' business world arising from growing international competition, growing technological innovations, complex financial sector, emerging knowledge economy and the rise in social media, greater transparency, rising consumer demands and protection and environment resources concern, all of which go a long way in determining their success or failure. The leadership stylescan have a significant impact on the survival and success of MSMEs. The leadership style determines how efficient resources are mobilize, allocated, and utilize towards the enhancement of organizational performance (Saasongu, 2015). Excellent leader not only inspires subordinate's potential to enhance efficiency but also meets their requirements in the process of achieving organizational goals (Lee and Chuang, 2009).

A full-range leadership theory (FRLT) which includes transformational, transactional and laissez-faire leadership styles was introduced by Bass, Avolio, \&Goodheim in 1987 before it was later extended by Antonakis and House (2004) to include instrumental leadership style due to the incomprehensive description of all the features of a leader in FRLT model as pointed out by Knippenberg\&Sitkin, 2013; and Antonakis\& House, 2004. With transformational (extraordinary) leadership the consciousness levels of followers about the importance and value of designated outcomes and ways of achieving them are raised by the leaders (Saasongu, 2015). Meanwhile, transactional leaders motivate followers by appealing to their self-interests and benefits in exchange of the work performed by them. In Laissezfaire leadership the leader provides insufficient guidance and input for the role the subordinates perform (Kumar, Pandey, Sinha and Srivastava, 2019). Whereas, instrumental leadership refers to the ability of a leader to achieve the goals set by the company by analyzing the internal and external environment of the company, outlining strategic objectives and providing performance feedback (Chammas and Hernandez, 2019). 
Due to multifaceted financial decisions confronting, owner-managers of MSMEs in running their business, financial literacy is another important tool for MSMEs performance since lack of knowledge of various aspects of financial decisions usually poses challenges which hinder performance of SMEs (Agyapong and Attram, 2019). Furthermore, financial literacy could enable owners/managers to be more creative in the use of credit and debt, the monitoring of budgets, the timely acquisition of raw material, production, fixed and variable costs and stock usage (Reich and Berman, 2015). It also enables owner-managers of SMEs to understand and assess their own financial needs and make rational financial decisions (Agyapong and Attram, 2019). Through improved financial literacy, more organize allotments of financial resources and to a considerable financial strength can be achieve (Eniola, and Entebang, 2016). According to OECD, (2013) where there is lack of financial literacy, there likelihood to make ill-informed financial decisions which could, in turn, had a tremendous negative spill-overs.

The existence of SMEs in Nigeria has often been plagued with slow growth, low sales, lack of expansion (Agyapong and Attram, 2019). In 2008, the Small and Medium Enterprise Development Agency of Nigeria (SMEDAN), reports that most small and medium scale businesses in Nigeria die before their fifth anniversary. According to Agyapong and Attram (2019) many small businesses fold up within the first 2 years while factors consisting of lack of knowledge, skills, attitude and awareness to cope and direct the finances in a hardy, transparent and professional were identified as significant obstacles to performance growth and the sustainability of such Ventures (Agyapong and Attram, 2019). Because of the important contribution of MSMEs to the economy, government, institutions and non-government agencies have over the years make several efforts to make MSMEs a viable productive unit and to promote MSMEs business operators or indigenous potential entrepreneurs (CBN, Edwinah Amah, 2017). Despite all government initiatives to stimulate MSMEs, and the institutional support towards making the MSMEs vibrant for improve performance, there is still much to be desire in terms of the contribution of MSMEs sector to the country's' economic growth and development (Basil 2005; Oshotimehin, Jegede, Akinlabi and Olajide, 2012).

Therefore, the main purpose of this study is to add to the literature of leadership in the context of Micro, Small and Medium Scale enterprises operating in Nigeria by analyzing the effect of leadership style and financial literacy on the survival of Micro, Small and Medium Scale Enterprises in Lagos State.

\subsection{Objectives of the Study}

The main purpose of the study is to assess the influence of leadership styles and financial competency on the survival of micro, small and medium scale enterprises in Lagos State. The specific objectives of the study are to determine:

- The extent to which the leadership styles of owners/managers influence the survival of MSMEs in Lagos State.

- The extent to which the financial literacy of owners/managers influence the survival of MSMEs in Lagos State.

- The extent to which financial literacy moderate the influence of leadership styles of owners/managers on the survival of MSMEs in Lagos State

The study will provide information that will benefit MSMEs firm's owners and managers in the area of improving their financial awareness, knowledge and competency and also to realize the importance of financial literacy in their effort to achieve success and improve performance. The remaining part of this study following this introductory section consist of the literature review in the second section, the methodology in third section and finally the discussion of result, conclusion and recommendations section.

\section{Literature Review}

\subsection{Theoretical Framework}

\subsubsection{Complexity leadership Theory (CLT)}

Complexity leadership Theory (CLT) Propounded by Uhl-Bien, Marion and McKelvey in 2007 and further specified by Uhl-Bien and Marion (2009). The reasons for using this theory are that majority of managers/owners in MSMEs frequently deploy leadership styles that do not capture the interest of employees in leadership roles or decision making. The managers believe that their role is to lead while that of employees is to follow. They take a practical look at organization and limitation of traditional leadership theory. CLT posits that Leadership is emergent processes that can occur through the interactions of individuals not just top-down bureaucratic influence. The proposed CLT moves leadership beyond the managerial logics of the industrial age to meet the new leadership requirements of the knowledge Era.

\subsubsection{The Efficient Frontier Theory}

The Efficient Frontier Theory was explained by Harry Markowitz and others in 1952 as a part of the Modern Portfolio Theory. The reasons for using this theory are that managers /leaders of MSMEs have many sources of funds each of which have their peculiar characteristic in term of risk, control and cost among which the manager need to select the most suitable one to help their business to survive and success. According to the concept of Efficient Frontier, there is a set of optimal portfolios which give the highest expected return for a given level of volatility and the lowest volatility for a given level of expected return. The choice of investments in the portfolio should be made in such a way that return is maximized and risk is minimized. Managers/owners of MSMEs can choose a suitable portfolio along the Efficient Frontier to achieve this objective, depending on their individual preferences and capability and competence.

Micro Small and Medium Enterprises (MSMEs) have continued to be recognized as the bedrock and powerful engines room for any nation's growth and development of most economies of the world (Ariyo, 2008; Yemi, 2017). The 
survival and success of MSMEs in the face of complexity in business environment, organisation structure and financial products in the financial sectors are necessary for these businesses to serve as an engine that lubricates the economic growth and development. However, the tasks of leadership couple with procurement and effective utilization of funds are becoming more complex for manager/owners of MSMEs. Managers have responsibility to give room for maximum connectivity of human resources for the MSMEs to easily learn in the constant changing environment for survival and success in the business operation.

\subsection{Leadership Styles and Survival of Small and Medium Scale Enterprises}

Leadership is one of the key determinants associated with the success and failure of any organization (Al Khajeh, 2018). It is defined in many ways by different author. Lohmann (1992) defined leadership as "the formulation of a vision, developing a climate of trust within the organization, and empowering others". It is a process whereby individuals influence groups of individuals to achieve a shared goal or commonly desired outcomes (Northouse, 2007). On the other end, Leadership styles is the approach a leader adopts in coordinating and motivating employees towards achieving a specific task (William, 2020). According to leadership style is the manner in which people are directed and motivated by a leader to achieve organizational goals (Al Khajeh, 2018).

There are different types of leadership styles proposed at different time to capture the dynamism of superior and subordinate relationship in the workplace. The first set of leadership styles referred to as full-range leadership theory (FRLT) was introduced by Bass, Avolio and Goodheim (1987) consisting of transformational, transactional and laissezfaire leadership styles. However, in order to bridge some identified lacuna in description of the features of a leader offered in the FRLT model among which are its omission of some leadership behaviours and its heroic conception of leadership (Yukl, 1999), an FRLT extended (eFRLT) model was adopted which introduced instrumental leadership to leadership styles defined in the original FRLT. Transformational leadership style is a style of leadership where the leaders use motivational tools to stimulate their workers through the creation and the representation of an inspiring vision of the future. In the same vein, Transactional leadership is a prototype of transformational leadership except that it is characterized by a more defined systems of However, contracts and rewards. In contrast, laissez-faire leadership is a passive leadership style in which leaders dodge responsibilities and avoid making decision. In the newly introduced instrumental leadership the leader aim to achieve the goals set by the company through the analysis of the internal and external environment of the company, outlining strategic objectives and providing performance feedback (Chammas and Hernandez, 2019). The two main factors in instrumental leadership are strategic leadership and job facilitation leadership. Strategic leadership includes strategic actions that affect processes and structures at the organizational level comprising of monitoring the environment and strategy formulation and implementation. The second factor presented by Antonakis and House (2004) is job facilitation leadership comprising of facilitating the route toward the objective and monitoring the performance or results (Chammas and Hernandez, 2019).

In the literature several studies abound linking either one or more leadership styles to organizational performance and survival as well as the aggregate leadership constructs on the attainment of the organizational goals. These studies however agreed that the leadership styles adopted play a significant role on organizational success. For instance, Saasongu (2015) studies the effect of leadership Style on organizational performance in Small and Medium Scale enterprises in Makurdi metropolis of Benue State, Nigeria using data was collected from 70 staff. The Friedman's ChiSquare statistics results show that transformational leadership style exert a positive but insignificant effect on employee performance while transactional leadership style has a positive significant effect on employee performance. It is concluded that transactional leadership style is more appropriate in inducing performance in small scale enterprises in Makurdi metropolis than transformational leadership style. In a similar vein, ChammasandHernandez (2019) investigate the influence of transformational and instrumental leadership on the individual performance of the employee and the financial performance in Brazilian startups through structural equation modeling applied on primary data collected from a sample of one hundred and twenty-six leaders of Brazilian startups. The results suggest that when leadership types are analyzed separately, both directly influence employee performance. Using the same Structural Equation Modeling (SEM) Huynh and Hua (2020) examines the relationship between task-oriented leadership style, psychological capital, job satisfaction and organizational commitment based on evidence from Vietnamese small and medium-sized enterprises based on data collected from a sample of 800 employees working in small and medium-sized enterprises in Vietnam. The results show that the task-oriented leadership style has a positive impact on organizational commitment, limits job satisfaction and no obvious association with the psychological capital of employees. Besides, job satisfaction and psychological capital play an important role in the organizational commitment of employees in small and medium-sized enterprises of Vietnam.

The available literature on the relationship between leadership styles and organization performance have focused mainly on leadership styles covering transformational, transactional, laissez faire, autocratic and democratic leadership styles but the role of instrumental leadership in the survivability of micro small and medium enterprises is rarely study in the literature. The sparse available studies with focus on instrumental leadership styles (Antonakis and House, 2014; Rowold, 2014; Chammas and Hernandez 2019) did not look at the role of financial literacy on the effect of leadership style on the survival of micro, small and medium scale enterprises. Meanwhile, irrespective of the leadership style adopted by a firm, financial literacy of the owners/managers goes a long way in determine the effectiveness of the leadership styles in impacting the organizational variables. It is based on this realization, that this study was motivated to address this lacuna, by investigating the influence of leadership styles and financial competency on the survival of micro, small and medium scale enterprises in Lagos State. It also examines extent to which financial literacy moderate the influence of leadership styles of owners/managers on the survival of MSMEs in Lagos State 


\subsection{Financial Competence and Survival of Small and Medium Scale Enterprises}

There is no universal agreed definition of financial competence the definition depends on who defines it. The definition of financial competence saddled legal, psychological and accounting domain. Kershaw \& Webber, 2002 define financial competence as the capacity to look after one's financial affairs. Willis (1996) reported that although psychological definitions focus on 'competence', legal definitions focus more on 'incapacity'. The accounting profession studying corporate governance focus on financial literacy and financial expertise in their attempt to define financial competence (Vinnari\&Näsi, 2013). However, no single method for assessing financial competence has gained widespread acceptance. Some literature reveals that the financial ratios are generally used when analyzing financial competency of firms seeking for credit from especially the banks (Oztemel E, Ozel S, 2018). Some of the professionals who complete competency assessments have little or no background or experience in assessment. Although psychologists are generally well trained in assessment issues, they are less familiar with the skills and abilities associated with specific competencies, such as financial competence (Allen, Martin, \& Allen, 2000; McCue \&Pramuka, 1998).

In Japan, Sakuraba et al. (2004) developed the Financial Competency Assessment Tool (FCAT) to assess adults with mental disorders. Although these performance-based measures have been used to assess financial competence in patients with Alzheimer's disease (AD). It consists of six subordinate domains of financial competence: basic monetary skills; financial conceptual knowledge; utilization of a banking institution; cash transaction; financial judgment; and understanding own income and expenditure. Hair, Anderson, Tatham, \& Black, 1995 use 6 factors as components of financial competence. They were: (1) everyday financial abilities; (2) financial judgment; (3) cognitive ability; (4) estate management; (5) debt management; and (6) support resources. Marson, 2001 identified and developed four different approaches to assessing financial capacity. These may be classified as (a) observational; (b) psychometric; (c) interview based; and (d) neuropsychological. Bateman \& Thorp assessed three dimensions of financial competence: numeracy, basic financial literacy and sophisticated financial literacy. Four components of financial competence are common with many authors namely, day-to-day financial problem solving, debt management, estate management, and financial judgement and decision-making (Webber, Reeve, Kershaw \& Charlton, 2002)

Several studies have explored the influence of financial competency or literacy on organizational performance and survival. For instance, Agyapong and Attram (2019) investigates the financial literacy of owner-managers of SMEs in the Cape Coast Metropolis and how such literacy influences the performance of their businesses. The study population were owner-managers of registered SMEs in the Cape Coast Metropolis from the National Board for Small and Medium Enterprise, out of which a sample of 132 was selected through the simple random sampling technique. The data was analyzed using Structural Equation Model. The results showed a positive relationship between financial literacy and the firm's financial performance. In the same vein, Eniola and Entebang (2017) examine the level of small and medium enterprises (SMEs) business owners- managers' financial literacy and its impact on firm's performance. The result of structural equation modelling (SEM) shows the complete effect of business owner-manager's financial knowledge, financial awareness and financial attitude in converting financial literacy to increase in firm performance. Also, they confirm that financial knowledge and awareness of SME business owners-managers are obviously not a prerequisite for the performance of SMEs, but entrepreneur characteristics in decision-making and relationship to financial attitude have a comparison with financial literacy. In the same vein, Vinnari and Nasi (2013) investigate municipal board members' financial and technical competence and analyze factors explaining the presence of such competence. Financial expertise estimates were constructed based on the board members' education and professional experience, while financial literacy levels were estimated based on prior board experience and participation in additional training in accounting and finance. Board members' technical competence was assessed in terms of their education. Quantitative data was derived from a survey administered to 354 municipal water utility board members in Finland. The response rate was $52 \%$. The results of the study indicate, first of all, that municipal board members estimated financial competence levels are not high and that financial competence is associated with organizational form. Secondly, board members' technical competence levels are also fairly low and technical competence is associated with political affiliation. In another study Bellofatto, D'Hondt, and Winne (2018) investigates the relationship between subjective financial literacy, i.e., self-reported by investors, and trading behavior. In particular, the study uses the level of financial knowledge and experience reported in the MiFID tests by retail investors. Such tests are implemented in the EU from the so-called Markets in Financial Instruments Directive since November 2007. The study show that subjective financial literacy helps explain cross-sectional variations in retail investors' behavior. Investors who report higher levels of financial literacy seem to invest smarter, even after controlling for gender, age, portfolio value, trading experience and education. They trade more and are less prone to the disposition effect. They tend to concentrate their portfolios on a small set of stocks and achieve diversification through investment funds holding. Their trading behaviors allow them to display higher gross and net returns as well as higher excess Sharpe ratios.

\section{Methodology}

The study was carried out in Lagos State Nigeria. Lagos State is the economic, financial and commercial nerve centre of Nigeria and ECOWAS (Lagos State Ministry of Commerce and Industry, 2011). The state is located in the south Western part of Nigeria, on the narrow plain of the Bight Benin, lying approximately on longitude 20 42'E and 32 2'E respectively, and between latitude 60 22'N and 60 2'N. Lagos State is bounded in the North and East by Ogun State of Nigeria, in the Republic of Benin, and stretches over 180 kilometers along the Guinea Coast of the Bight of Benin of the Atlantic Ocean. Its territorial extent and political jurisdiction encompass the city of Lagos and the four administrative divisions of Ikeja, Ikorodu, Epe and Badagry collectively refer to as IBILE and covering an area of 358,862 hectares or $3,577 \mathrm{sq} . \mathrm{km}$ which represents $0.4 \%$ of Nigeria's territorial landmass of $923,773 \mathrm{sq} . \mathrm{km}$. Lagos State is politically divided into 
twenty (20) Local Government Areas of which three (3) Local Government Areas: Lagos Island, Ikeja and Epe will be used for the study.

\subsection{Design of the Study}

The design of the study is descriptive survey research. This design is suitable for the study since the data to be collected would be through the questionnaire from owners/managers and employees of MSMEs on the leadership styles and financial competency.

\subsection{Targeted Population}

The population of the study comprised 4,514 Micro Small and Medium Scale Enterprises in Ikeja, Lagos Island and Epe Local Government Area of Lagos State. There are 2518, 1003 and 993 MSMEs in Ikeja, Island and Epe Local Government Area respectively (Ministry of Commerce and Industry, 2012). Only the list of enterprises, address and telephone line were found in the Lagos Business Directory published by Ministry of Commerce and Industry. The database of the managers and employees of enterprises are not available in the directory. The Table 1 below shows the details of the population for the study:

\begin{tabular}{|c|c|c|c|c|}
\hline LOCAL GOVT. & ISLAND & IKEJA & EPE & TOTAL \\
\hline NUMBER OF MSMEs & 1003 & 2518 & 993 & 4514 \\
\hline
\end{tabular}

Table 1: Population of the Study

Source: Ministry of Commerce and Industry, 2011

\subsection{Sample and Sampling Technique}

The sample size was eight hundred and thirteen (813) MSMEs staff comprising two hundred and seventy-one (271) owners/managers and five hundred and forty-two (542) employees randomly selected from seventy-four (271) MSMEs from a random sample of three Local Government Areas. The sampling technique that was adopted in this study was multi-stage. Firstly, through simple random sampling the three senatorial districts were selected in Lagos State and these are Lagos Central, Lagos West and Lagos East Senatorial district. Secondly, one local government each was randomly selected from the three Senatorial districts. Out of five local governments in Lagos Central Senatorial District, Island Local government (ILD) is randomly selected while out of ten local governments in Lagos West Senatorial District, Ikeja local government (IKJ) is randomly selected. Out of five local governments in Lagos East Senatorial District Epe local government (EPE) is randomly selected. Thirdly, fifty-three and twenty-one MSMEs was randomly selected in Ikeja and Island Local Government Area respectively. In all two hundred and seventy-one (271) owners/managers and five hundred and forty-eight (542) employees will be randomly selected in ratio one and two (1: 2) respectively from each enterprise in the two local governments. The table below shows the details of the sample for the study:

\begin{tabular}{|c|c|c|c|c|c|}
\hline $\mathbf{1}^{\text {st }}$ Stage & 2 $^{\text {nd }}$ Stage & 3 $^{\text {rd }}$ Stage & \multicolumn{2}{|c|}{$\mathbf{4}^{\text {th }}$ StageSelected on 1:2 } & Employees \\
\hline $\begin{array}{c}\text { Senatorial } \\
\text { District. }\end{array}$ & Local Govt. & $\begin{array}{c}\text { MSMEs } \\
\text { Sampled }\end{array}$ & $\begin{array}{c}\text { Managers } \\
\text { /Leaders }\end{array}$ & Total \\
\hline Lagos West & Ikeja & 151 & $15 \mathrm{I}$ & 302 & 453 \\
\hline Lagos Central & Island & 60 & 60 & 120 & 180 \\
\hline Lagos East & Island & 60 & 60 & 120 & 180 \\
\hline & Total & 271 & 271 & 542 & 813 \\
\hline
\end{tabular}

Table 2: Sample and Sampling Technique

Source: Authors' Survey, 2021

\section{Data Analysis}

\subsection{Research Instrument}

This study explores the influence of leadership styles and financial literacy on the survival of micro, small and medium scale enterprises in Lagos state, southwest Nigeria. In addition to the five traditional leadership styles comprising of transactional (TRN), democratic (DMR), transformational (TRF), charismatic (CRT), and laissez faire (LSF) leadership styles that are frequently used in the literature. We introduced instrumental (ISM) leadership in our measure of leadership styles. In the measurement of leadership styles, we used the multifactor leadership questionnaire (MLQ) introduced by Avolio and Bass, (2004) covering transactional, transformational and laissez-faire leadership styles. The Democratic leadership style was drawn from leadership style questionnaire developed by Northouse (2011) comprising three subscales with 18 items measuring autocratic, democratic and laissez-faire leadership styles while the charismatic leadership style was measure using charismatic leadership behavioural dimensions developed by Conger and Kanungo (1994). Instrumental leadership styles were measured by instrumental leadership scale containing eight variables as used by Antonakis and House, (2014). In line with Eniola and Entebang (2016), financial literacy was captured using three different but related proxies comprising financial knowledge FKG (Lusardi and BassaScheresberg, 2013), financial awareness FAW (Sulaiman, 2014) and financial attitude FAT (Covin and Slevin, 1989; Cude, 2010). To capture the survival of micro, small and medium scale enterprises SMSME we used Mac and Bhaird (2010) and Digne and Zeller small and medium scale enterprises performance scale. 


\subsection{Reliability Testing}

We checked for the reliability and validity of the research instruments using three main criteria comprising of composite reliability (CR) which is similar to Cronbach alpha measure, average bv varianceextracted (AVE) which measure the amount of variance captured by a construct's measures related to random measurement error (Chammas and Hernandez, 2019). An AVE estimates of above 0.50 and CR estimates bigger than 0.60 imply that the instrument has a good internal consistency and Cronbach's Alpha (CA) with results above 0.7 considered reliable (Chammas and Hernandez, 2019).

\begin{tabular}{|c|c|c|c|c|c|c|c|}
\hline & Items & $\mathbf{M}$ & SD & Loading & CA & CR & AVE \\
\hline TRF -1 & \multirow[b]{3}{*}{3} & \multirow[t]{3}{*}{5.211} & \multirow{3}{*}{0.600} & 0.421 & \multirow{3}{*}{0.721} & \multirow{3}{*}{0.732} & \multirow[t]{3}{*}{0.559} \\
\hline TRF -2 & & & & 0.723 & & & \\
\hline TRF -3 & & & & 0.686 & & & \\
\hline TRN -1 & \multirow[t]{4}{*}{4} & \multirow[t]{4}{*}{4.222} & \multirow[t]{4}{*}{0.552} & 0.816 & \multirow[t]{4}{*}{0.832} & \multirow[t]{4}{*}{0.724} & \multirow[t]{4}{*}{0.765} \\
\hline TRN -2 & & & & 0.977 & & & \\
\hline TRN -3 & & & & 0.783 & & & \\
\hline TRN -4 & & & & 0.865 & & & \\
\hline DMR - 1 & \multirow[t]{5}{*}{5} & \multirow[t]{5}{*}{5.501} & \multirow[t]{5}{*}{0,611} & 0.961 & \multirow[t]{5}{*}{0.821} & \multirow[t]{5}{*}{0.731} & \multirow[t]{5}{*}{0.761} \\
\hline DMR - 2 & & & & 0.797 & & & \\
\hline DMR - 3 & & & & 0.763 & & & \\
\hline DMR - 4 & & & & 0.874 & & & \\
\hline DMR - 5 & & & & 0.576 & & & \\
\hline CRT - 1 & \multirow[t]{4}{*}{4} & \multirow[t]{4}{*}{4.3211} & \multirow[t]{4}{*}{0.531} & 0.732 & \multirow[t]{4}{*}{0.711} & \multirow[t]{4}{*}{0.832} & \multirow[t]{4}{*}{0.787} \\
\hline CRT - 2 & & & & 0.765 & & & \\
\hline CRT - 3 & & & & 0.898 & & & \\
\hline CRT - 4 & & & & 0.877 & & & \\
\hline LSF - 1 & \multirow[t]{5}{*}{5} & \multirow[t]{5}{*}{4.521} & \multirow[t]{5}{*}{0.661} & 0.782 & \multirow[t]{5}{*}{0.783} & 0.2814 & 0.811 \\
\hline LSF - 2 & & & & 0.778 & & & \\
\hline LSF - 3 & & & & 0.456 & & & \\
\hline LSF - 4 & & & & 0.566 & & & \\
\hline LSF - 5 & & & & 0.686 & & & \\
\hline ISM - 1 & 5 & 5.3 & 0.611 & 0.866 & 0.672 & 0.864 & 0.743 \\
\hline ISM - 2 & & & & 0.787 & & & \\
\hline ISM - 3 & & & & 0.923 & & & \\
\hline ISM - 4 & & & & 0.457 & & & \\
\hline ISM - 5 & & & & 0.787 & & & \\
\hline FKG - 1 & 2 & 5.011 & 0.592 & 0.643 & 0.821 & 0768 & 0.952 \\
\hline FKG - 2 & & & & 0.576 & & & \\
\hline FAW - 1 & 3 & 4.051 & 0.633 & 0.876 & 0.718 & 0.852 & 0.812 \\
\hline FAW - 2 & & & & 0.635 & & & \\
\hline FAW - 3 & & & & 0.755 & & & \\
\hline FAT - 1 & 2 & 5.222 & 0.7462 & 0.9123 & 0.900 & 0.724 & 0.765 \\
\hline FAT -2 & & & & 0.8113 & & & \\
\hline SMSME - 1 & 1 & 4.890 & 0.812 & 0.8452 & 0.841 & 0.967 & 0.885 \\
\hline
\end{tabular}

Table 3: Descriptive, Validity and Reliability

Source: Authors' Survey, 2021

The Cronbach's alpha for transactional democratic (DMR), transformational (TRF), charismatic (CRT), laissez faire (LS), instrumental (ISM) leadership styles, financial knowledge FKG, financial awareness FAW, financial attitude FAT, and survival of micro, small and medium scale enterprises SMSME were found to be higher than 0.7, while the Cronbach's alpha value for instrumental leadership was found to be 0.672 . Therefore, all the items used can be considered reliable. Also, the AVE values for all the variables were found to be greater than 0.50 indicating acceptable convergent validity. Looking at the discriminant validity, all the indicator loadings are greater than 0.7 while the cross-loading also shows that all the indicators' loadings are higher than the entire cross-loadings confirming discriminants validity. 


\subsection{Structural Equation Modelling}

\begin{tabular}{|c|c|c|c|}
\hline Loading & Coefficients & p value & Decision \\
\hline $\mathrm{DMR} \rightarrow$ SMSME & 0.06 & 0.343 & Accept \\
\hline $\mathrm{TRF} \rightarrow$ SMSME & 0.405 & 0.021 & Reject \\
\hline $\mathrm{CRT} \rightarrow$ SMSME & 0.166 & 0.008 & Reject \\
\hline $\mathrm{LS} \rightarrow$ SMSME & 0.084 & 0.507 & Accept \\
\hline ISM $\rightarrow$ SMSME & 0.243 & 0.167 & Accept \\
\hline FKG $\rightarrow$ SMSME & 0.100 & 0.682 & Accept \\
\hline FAW $\rightarrow$ SMSME & 0.411 & 0.871 & Accept \\
\hline FAT $\rightarrow$ SMSME & -0.052 & 0.020 & Reject \\
\hline
\end{tabular}

Table 4: Path Coefficients

Source: Authors' Survey, 2021

Table4 illustrates that at 5\% level of significance the null hypothesis that transformational and charismatic leadership styles as well as financial knowledge do not have a significant effect on the survival of micro, small and medium scale enterprises can be rejected. This implies that transformational and charismatic leadership styles exert a significant positive influence while financial knowledge exerts a significant negative influence on the survival of micro, small and medium scale enterprises in Lagos State. Furthermore, the Table 2 suggest that we cannot reject the null hypotheses that democratic, laissez faire and instrumental leadership styles as well as financial knowledge, and financial awareness do not have a significant effect on the survival of micro, small and medium scale enterprises. This implies that, democratic, laissez faire and instrumental leadership styles as well as financial knowledge, and financial awareness do not have a significant effect on the survival of micro, small and medium scale enterprises Lagos State.

\section{Discussion}

The goal of the current study was to explore the influence of leadership styles and financial literacy on the survival of micro, small and medium scale enterprises in Lagos State, southwest Nigeria. The findings from the study revealed transformational and charismatic leadership styles exert a significant positive influence while financial knowledge exerts a significant negative influence on the survival of micro, small and medium scale enterprises in Lagos State. It further shows that democratic, laissez faire and instrumental leadership styles as well as financial knowledge, and financial awareness do not have a significant effect on the survival of micro, small and medium scale enterprises Lagos state. By and large, it is evident that both financial literacy and leadership styles do not have a significant effect on the survival of micro, small and medium scale enterprises in Lagos State. Out of the three measures of financial literacy tested only financial attitude was found to be significant and it is even negative.

The results supported is corroborated Saasongu (2015) on the effect of leadership Style on organizational performance in Small and Medium Scale enterprises in Makurdi metropolis of Benue State. The study concluded that transactional leadership style is more appropriate in inducing performance in small scale enterprises in Makurdi metropolis than transformational leadership style. In a similar vein, Chammas and Hernandez (2019) on the influence of transformational and instrumental leadership on the individual performance of the employee and the financial performance in Brazilian startups. The results suggest that when leadership types are analyzed separately, both directly influence employee performance.

The result is also in line with Agyapong and Attram (2019) on financial literacy of owner-managers of SMEs in the Cape Coast Metropolis. The results showed a positive relationship between financial literacy and the firm's financial performance. In the same vein, Vinnari and Nasi (2013) studied municipal board members' financial and technical competence and analyze factors explaining the presence of such competence. The results of the study indicate, first of all, that municipal board members estimated financial competence levels are not high and that financial competence is associated with organizational form. Secondly, board members' technical competence levels are also fairly low and technical competence is associated with political affiliation.

\section{Conclusion and Recommendations}

For the leadership styles, it was observed that leadership styles do not have significant effect on the survival of micro, small and medium scale enterprises in Lagos State since it is only charismatic and transformational leadership styles were found to exert positive effect on the survival of micro, small and medium scale enterprises in Lagos State out of the six leadership traits tested. In conclusion, transformational and charismatic leadership styles yield positively to the survival of MSMEs managers/owners possess the adequate knowledge in financial competency. The following recommendations were made based on the results of the study:

Business owners in the study area were found to be more in transformational and charismatic leadership styles than financial knowledge influence in the survival of MSMEs

Small business owners in the study area requires information on how survival of the business could be fortified through assess to credit.

Training and retraining are also required in the area of financial literacy to be financially competent. 


\section{References}

i. Abdul, R.O (2019) Effect of entrepreneurial competencies on the survival of small and medium enterprises in Kenya, doctor of philosophy in entrepreneurship, School of Business, School of Entrepreneurship, Procurement and Management,School of Communication and Development Studies, Jomo Kenyatta University of Agriculture and Technology

ii. Agyapong, D. and Attram, A.B (2019) Effect of owner-manager's financial literacy on the performance of SMEs in the Cape Coast Metropolis in Ghana, Agyapong and AttramJournal of Global Entrepreneurship Research. 9:67

iii. Akabueze B (2002). Prospectus on Nigeria SMEs under the Small and Medium Industries Investment Scheme (SMIEIS). Accessed August 142009 from www.nigeriabusinessinfor.com/nigerian-smes2000.htm

iv. Al Khajeh, E. H. (2018). Impact of leadership styles on organizational performance. Retrieved on October 10 , 2019 from https://ibimapublishing.com/articles/JHRMR/2018/687849/687849-1.pdf

v. Al Mamun, A., Fazal, S.A. \&Zainol, N.R (2019): Economic Vulnerability, Entrepreneurial Competencies, and Performance of Informal Micro-Enterprises, Journal of Poverty, DOI: 10.1080/10875549.2019.1587676

vi. Antonakis, J., \& House, R. J. (2004). On instrumental leadership: Beyond transactions and transformations. Paper presented at the Gallup Leadership Institute Conference, University of Nebraska.

vii. Ariyo, D. (2008). Small Firms are the Backbone of the Nigeria Economy. Retrieved from https://www.africaeconomicanalysis.orglarticle/genl smallhtm.html

viii. Basil, A.N.O. (2005) Small and Medium Enterprises (SMEs) in Nigeria: Problems and Prospects. Unpublished $\mathrm{Ph}$ D. thesis. St. Clements University, Australia

ix. Bass, B. M., Avolio, B. J., \&Goodheim, L. (1987). Journal of Management. https://doi.org/10.1177/014920638701300102

x. Bellofatto, A., D'Hondt, C. Winne, R.D (2018) Journal of Banking and Finance journal homepage: www.elsevier.com/locate/jbf Subjective financial literacy and retail investors' behavior, Journal of Banking and Finance 92, 168-181

xi. Chammas, C.B., and Hernandez, J.M.D (2019) Comparing transformational and instrumental leadership: The influence of different leadership styles on individual employee and financial performance in Brazilian startups, Innovation \& Management Review,16 (2) 143-160

xii. Conger, J.A. and Kanungo, R.A. (1994). Charismatic leadership in organizations: Perceived behavioral attributes and their measurement. Journal of Organizational Behavior, 15: 439-452.

xiii. Cooper, A. C. (1993) Challenges in predicting new firm performance. Journal of Business Venturing. Vol. 8, No.3, 241-254.

xiv. Covin, J.G., Slevin, D.P. (1989). Strategic management of small firms in hostile and benign environments. Strategic Management Journal, 10(1), 75-87.

xv. Cude, B.J. (2010). Financial literacy. Journal of Consumer Affairs: Official Publication of the American Council on Consumer Interests, 44(2), 271-275

xvi. Eniola, A.A and Entebang, H. (2016). Financial literacy and SME firm performance, International Journal of Research Studies in Management, 5(1), 31-43

xvii. Eniola, A.A and Entebang, H. (2017) SME Managers and Financial Literacy, SME Managers and Financial Literacy, Global Business Review18(3) 1-18

xviii. Huynh, T.N and Hua, N.T.A (2020) The relationship between task-oriented leadership style, psychological capital, job satisfaction and organizational commitment: evidence from Vietnamese small and medium sized enterprises, Journal of Advances in Management Research, DOI 10.1108/JAMR-03-2020-0036

xix. Kalleberg AL, Leicht KT (1991) Gender and organizational performance: Determinants of small business survival and success. Academic Management Journal 34(1):136-161

xx. Kershaw, M., \& Webber, L. (2008). Assessment of Financial Competence. Psychiatry, Psychology and Law, 15(1), 40

xxi. Knippenberg, D.V. \&Sitkin, S.B. (2013). A critical assessment of charismatic-transformational leadership research: Back to the drawing board? Academy of Management Annals, 7, 1-60.

xxii. Kumar, M., Pandey, S., Sinha, V., and Srivastava, A.P (2019) Influence of leadership styles of bankers in decision Making on loans to start-up entrepreneurs, Journal of Developmental Entrepreneurship, 24(4), DOI: $10.1142 / \mathrm{S} 1084946719500250$

xxiii. Lee and Chuang (2009). The Impact of Leadership Styles on Job Stress and Turnover Intention: Taiwan Insurance Industry as an Example.www.hclee@ttu.edu.tw

xxiv. Lohmann, D. (1992). The impact of leadership on corporate success: A comparative analysis of the American and Japanese experience. In K. E. Clark, M. B., Clark, \& D. P. Campbell (Eds.), Impact of leadership (pp. 59-80). Greensboro, NC: Center for Creative Leadership.

xxv. Longe, O, J (2014) Leadership Style Paradigm Shift and Organizational Performance: A Case of the Nigerian Cement Industry, An International Multidisciplinary Journal, Ethiopia Vol. 8(4), Serial No. 35, September, 2014:68-83, DOI: http://dx.doi.org/10.4314/afrrev.v8i4.6

xxvi. Lusardi, A., Scheresberg, C.D. (2013). Financial literacy and high-cost borrowing in the United States (Working Paper Series/National Bureau of Economic Research). Cambridge, MA: National Bureau of Economic Research.

xxvii. Manzoor, F., Wei, L., Nurunnabi, M., Subhan, Q.A., Shah, S.I.A and Fallatah, S. (2019) The Impact of Transformational Leadership on Job Performance and CSR as Mediator in SMEs, Sustainability 2019, 11, 436; doi:10.3390/su11020436 
xxviii. Marion R. and Uhl-Bien, M. (2007). Complexity and strategic leadership. In: R. Hooijberg, J. Hunt, J. Antonakis, K. Boal, and N. Lane, Editors, Being there even when you are not: Leading through structures, systems, and processes, Elsevier, Amsterdam

xxix. Marson D. C. (2001). Loss of financial capacity in dementia: Conceptual and empirical approaches. Aging, Neuropsychology and Cognition, 8, 164-181.

xxx. McCue, M., Pramuka, M. (1998). Functional assessment G. Goldstein S. Beers (Eds). Rehabilitation, Plenum Press, New York.

xxxi. McKelvey, B. (2001). Energizing order-creating networks of distributed intelligence, International Journal of Innovation Management 5, 181-212

xxxii. National Bureau of statistics (NBS) \&The small and medium Enterprises Development Agency of Nigeria (SMEDAN), (2012), survey report on micro, small and medium enterprises (MSMES) in Nigeria preliminary report 2010 National MSME collaborative survey.

xxxiii. National Bureau of statistics (NBS) \&The small and medium Enterprises Development Agency of Nigeria (SMEDAN), (2013), Survey Report on Micro, Small and Medium Enterprises (MSMEs) in Nigeria. SMEDAN and National Bureau of Statistics Collaborative Survey: Selected Findings (2013).

xxxiv. NBS/SMEDAN (2016). Survey Report on Micro, Small and Medium Enterprises (MSMEs) in Nigeria. National MSMEs Collaborative Survey between National Bureau of Statistics and Small and Medium Enterprises Development Agency of Nigeria.

xxxv. Neneh, B.N. (2011). The impact of entrepreneurial characteristics and business practices on the long-term survival of small and medium enterprises (SMEs). Master's thesis. University of Free State.

xxxvi. Northouse, G. (2007). Leadership Theory and Practice. (3rd ed.) Thousand Oaks, CA: Sage Publications.

xxxvii. Obiwuru, T.C., Okwu, A.T., Akpa, V.O. and Nwankwere, I.A (2011) Effects of leadership style on organizational performance: A survey of selected small-scale enterprises in ikosi-ketuCouncil development area of lagos state, Nigeria, Australian Journal of Business and Management Research Vol.1 No.7

xxxviii. OECD (2013). OECD/info toolkit to measure financial literacy and financial inclusion: guidance, core questionnaire and supplementary questions. Retrieved from http://www.oecd.org/finance/financialeducation/Toolkit-to-measure-fin-lit-2013.pdf

xxxix. Osotimehin K. O., Jegede C. A., Akinlabi B. H. \&Olajide O. T. (2012), An Evaluation of the Challenges and Prospects of Micro and Small-Scale Enterprises Development in Nigeria: American International Journal of Contemporary Research, Vol. 2 No. 4 pp $174-185$.

xl. Oztemel E, Ozel S (2018) Financial Competency Assessment Model. Journal Business Financial Affairs 7: 317

xli. Reich, C. M., \& Berman, J. S. (2015). Do financial literacy classes help? An experimental assessment in a lowincome population. Journal of Social Service Research, 41(2), 193-203.

xlii. Saasongu, N. (2015) Effects of Leadership Style on Organizational Performance in Small and Medium Scale Enterprises (SMES) in Nigeria, International Journal of Research in Management, 2

xliii. Sakuraba Y, Kumawzawa Y, Matsuda O (2004). Development of the Financial Competency Assessment Tool (FCAT): a study of the reliability and validity of the FCAT. Bull Tokyo Gakugei University Section I Science Education.55:131-9.

xliv. Sanusi, J. (2004). Keynote address by the Governor of the Central Bank of Nigeria. Presented at the national summit on "Revamping Small and Medium Industries" organized by the Manufacturers Association of Nigeria (MAN), Lagos, Nigeria.

xlv. Sanusi, J.0. (2003a). Overview of government's effort in the development of SMEs and the emergence of small and medium industries equity investment scheme (SMIEIS). Presented at the National Summit on SMIEIS organized by the Bankers' Committee and Lagos Chamber of Commerce and Industry (LCCI), Lagos, Nigeria,

xlvi. Sanusi, J.O. (2003b). Progress report on the small and medium industries equity investment scheme (SMIEIS) for July: Central Bank of Nigeria's perspective. Available: http://www.cenbank.org/smi-GOVADD16JUL.pdf,

xlvii. SMEDAN (2007), 'National Policy on Micro, Small and Medium Enterprises.' $<<$

xlviii. http://www.smedan.gov.ng/search.php?searWords=National\%20policy\%20on\%20MSMEs

xlix. SMEDAN. National Policy on Micro, Small and Medium Enterprises (MSMEs) in Nigeria (2016). A Policy Document Prepared by Small and Medium Enterprises Development Agency of Nigeria and Approved by the Federal Executive Council.

1. SMIEIS (2005). Investments by banks: Central Bank of Nigeria's progress report on small and medium industries equity investment scheme (SMIEIS) for February 2005. Available: http://www.cenbank.org/SMIEIS\%20REPO RT\%20\%20FEB05.pdf, retrieved on 27 April 2005.

li. SMIEIS. (2002). Prospects of Nigerian SMEs under the small and medium industries equity investment scheme. Available: http://www.nigeriabusinessinfo.com/news.htm.

lii. Sulaiman, N. (2014). Clarifying the financial literacy dimensions for the performance of small and medium enterprises. In Economic Forum of Entrepreneurship \& International Business, London University Institute in Paris, Paris, France: ECO-ENA: Economics \& ECO-Engineering Associate, Inc., Canada.

liii. Udechukwu, F.N. (2003). Survey of small and medium scale industries and their potentials in Nigeria. Proc. Seminar on Small and Medium Industries Equity Investment Scheme (SMIEIS), Central Bank of Nigeria (CBN) training Centre, Lagos, Nigeria, pp. 6-18. 
liv. Uhl-Bien, M., Marion, R., \&McKelvey, B. (2007). Complexity leadership theory: Shifting leadership from the industrial age to the knowledge era. The Leadership Quarterly, 18(4), 298-318.

lv. Vinnari, E., and Nasi, S. (2013) Financial and technical competence of municipal board members: Empirical evidence from the water sector, Critical Perspectives on Accounting 24, 488-501

lvi. Webber, L., Reeve, R., Kershaw, M. \& Charlton, J. (2002). Assessing financial competence. Psychiatry, Psychology and Law, 9(2), 248-256. doi:10.1375/pplt.2002.9.2.248

lvii. William, O.E (2020) The effects of leadership styles on employee engagement in small and medium enterprises in Nigeria, Master of Science in International Business Submitted to the National College of Ireland

lviii. Williams, A. J. (2020). The effects of police officer supervisory training on self-esteem and leadership style adaptability considering the impact of life experiences. Unpublished doctoral dissertation, Georgia State University.

lix. Willis, J (1996) A Framework for Task-based Learning. London: Longman

lx. Yemi Kale, (2015), Micro, Small and Medium Enterprise National Survey 2013, National Bureau of Statistics, Nigeria.

lxi. Yukl, G. (1999). Managerial leadership: A review of theory and research. Journal of Management, 15, 251-289.

lxii. Yukl, G. A. (1994). Leadership in organizations. Englewood Cliffs, NJ: Prentice Hall. 